\title{
Peningkatan Kemampuan Komunikasi Matematis Siswa Melalui Model Pembelajaran CORE dengan Pendekatan Scientific
}

\author{
Ria Deswita ${ }^{1, \text { a) }}$, Yaya S. Kusumah ${ }^{2}$, Jarnawi A. Dahlan ${ }^{2}$ \\ ${ }^{I}$ Fakultas Tarbiyah dan Ilmu Keguruan IAIN Kerinci \\ ${ }^{2}$ Universitas Pendidikan Indonesia \\ a) ria_deswita@ymail.com
}

\begin{abstract}
This research is motivated by the importance of mathematical communication ability. But the reality shows that students' mathematical communication ability is still low. So that problem can be overcome, we need a learning model that can improve students' mathematical communication ability. Therefore, a Connecting-Organizing-Reflecting-Extending (CORE) learning model was chosen with a scientific approach. This study aims to examine the improvement of mathematical communication skills. This research is a quasi-experimental research with nonequivalent control group design. The population in this study is all students of class VIII in one of SMP Negeri in Jambi province. The sample consists of two classes selected by purposive sampling. The instrument used is a test of mathematical communication ability. Data analysis using independent $t$-test. Based on data analysis, it was found that the improvement of mathematical communication ability of students who obtained CORE model learning with scientific approach is better than students who get conventional learning.
\end{abstract}

Keywords: CORE Model Learning, Scientific Approach, Mathematical Communication Ability

\begin{abstract}
Abstrak.Penelitian ini dilatarbelakangi oleh pentingnya kemampuan komunikasi matematis. Namun kenyataan di lapangan menunjukkan bahwa kemampuan komunikasi matematis siswa masih rendah. Agar permasalahan tersebut dapat diatasi, diperlukan sebuah model pembelajaran yang dapat meningkatkan kemampuan komunikasi matematis siswa. Oleh karena itu, dipilih model pembelajaran Connecting-Organizing-Reflecting-Extending (CORE) dengan pendekatan saintifik. Penelitian ini bertujuan untuk menelaah peningkatan kemampuan komunikasi matematis. Penelitian ini merupakan penelitian kuasi eksperimen dengan desain nonequivalent control group design. Populasi pada penelitian ini adalah seluruh siswa kelas VIII pada salah satu SMP Negeri di provinsi Jambi. Sampel terdiri dari dua kelas yang dipilih secara purposive sampling.Instrumen yang digunakan berupa tes kemampuan komunikasi matematis. Analisis data menggunakan Independent t-test. Berdasarkan analisis data, ditemukan bahwa peningkatan kemampuan komunikasi matematis siswa yang memperoleh pembelajaran model CORE dengan pendekatan saintifiklebih baik daripada siswa yang memperoleh pembelajaran biasa.
\end{abstract}

Kata kunci:Model Pembelajaran CORE, Pendekatan Saintifik, Kemampuan Komunikasi Matematis 


\section{PENDAHULUAN}

Kemampuan komunikasi matematis merupakan kemampuan yang harus dimiliki oleh siswa sekolah menengah. Seperti yang tercantum pada tujuan pembelajaran dalam kurikulum tingkat satuan pendidikan (KTSP) pada poin keempat, yaitu agar siswa mampu mengomunikasikan gagasan dengan simbol, tabel, diagram, atau media lain untuk memperjelas keadaan atau masalah. Selain itu, pada kurikulum 2013 salah satu kompetensi matematika yang harus dicapai siswa adalah memiliki kemampuan mengomunikasikan gagasan matematis dengan jelas dan efektif (Permendikbud no 64, 2013). Komunikasi matematis juga merupakan salah satu standar proses dalam pembelajaran matematika dalam NCTM. Baroody (1998, hlm. 22) menyebutkan sedikitnya ada dua alasan penting, mengapa komunikasi dalam pembelajaran matematika perlu ditumbuhkembangkan di kalangan siswa, diantaranya: matematika tidak hanya sekedar alat bantu berpikir, alat bantu menemukan pola, menyelesaikan masalah atau mengambil kesimpulan, tetapi matematika juga sebagai aktivitas sosial dalam pembelajaran; matematika sebagai wahana interaksi antar siswadan juga antar guru dan siswa. Hal ini menunjukkan bahwa komunikasi matematis merupakan salah satu kemampuan penting yang harus dikembangkan dalam diri siswa. Pentingnya kemampuan komunikasi matematis juga diungkap Sumarmo (2010), bahwa komunikasi matematis merupakan komponen penting dalam belajar matematika, alat untuk bertukar ide, dan mengklarifikasi pemahaman matematis.

Menurut NCTM (2000, hlm. 60), komunikasi matematis merupakan suatu cara siswa untuk mengungkapkan ide-ide matematis baik secara lisan, tertulis, gambar, diagram, menggunakan benda, menyajikan dalam bentuk aljabar, atau menggunakan simbol matematis. Sumarmo (2014, hlm. 7)merinci karakteristik kemampuan komunikasi matematis ke dalam beberapa indikator, sebagai berikut: menyatakan suatu situasi atau masalah ke dalam bentuk bahasa, simbol, idea, atau model matematik (dapat berbentuk gambar, diagram, grafik, atau ekspresi matematik); menjelaskan idea, situasi, dan relasi matematika dalam bentuk bahasa biasa; mendengarkan, berdiskusi, dan menulis tentang matematika; memahami suatu representasi matematika; mengungkapkan kembali suatu uraian matematika dalam bahasa sendiri.

Realitas saat ini menunjukkan bahwa kemampuan komunikasi matematis siswa masih rendah. Berdasarkan hasil observasi pada salah satu SMP Negeri di Provinsi Jambi, diperoleh bahwa siswa belum mampu mengomunikasikan ide matematis dengan baik.Siswa belum mampu menyampaikan ide-ide mereka. Saat guru bertanya, siswa masih belum mampu menyusun argumen dengan baik. Pembelajaran masih didominansi atau berpusat pada guru. Serta siswa juga belum mampu menyatakan suatu situasi atau masalah ke dalam bentuk simbol, diagram, atau model matematis. Dengan demikian, dapat dikatakan bahwa kemampuan komunikasi matematis siswa masih rendah (Hariyanto, 2016). Rendahnya kemampuan komunikasi matematis juga ditunjukkan dalam penelitian Zulkarnain (2013), ia menyatakan bahwa siswa belum mampu mengomunikasikan ide secara baik, terdapat jawaban siswa yang keliru terhadap soal yang diberikan dan langkah perhitungan yang dilakukan siswa belum terorganisir dengan baik dan tidak konsisten. Siswa belum sepenuhnya mampu memberikan argumentasi yang didasarkan pada prinsip dan konsep matematis.

Agar permasalahan tersebut dapat diatasi, diperlukan sebuah model pembelajaran matematika yang dapat membuat pembelajaran menjadi bermakna, sehingga kemampuan matematis siswa dapat meningkat. Oleh karena itu, dipilih model pembelajaran ConnectingOrganizing-Reflecting-Extending (CORE) (Fadhilah Al Humaira, Suherman, Jazwinarti. (2014). Menurut Jacob (Wijayanti, 2012, hlm. 15) CORE adalah salah satu model pembelajaran yang berlandaskan pada konstruktivisme. Dengan kata lain, model pembelajaran CORE merupakan model pembelajaran yang dapat digunakan untuk membuat siswa aktif dalam membangun pengetahuannya sendiri. Dalam membangun pengetahuannya sendiri, siswa diharuskan berinteraksi dengan lingkungannya. Calfee, et al(2004) menyatakan bahwa yang dimaksud pembelajaran model CORE adalah model pembelajaran yang membuat siswa mengkonstruksi pengetahuannya sendiri dengan cara menghubungkan (connecting) dan mengorganisasikan (organizing) pengetahuan baru dengan pengetahuan lama kemudian memikirkan konsep yang sedang dipelajari (reflecting) serta 
siswa dapat memperluas pengetahuan mereka selama proses belajar mengajar berlangsung (extending). Agar model pembelajaran CORE dapat berlangsung dengan baik dan mencapai tujuan yang diharapkan maka perlu dilakukan pendekatan pembelajaran yang mendukung model pembelajaran CORE salah satunya adalah pendekatan scientific.

Pendekatan scientific merupakan suatu cara atau mekanisme untuk mendapatkan pengetahuan dengan prosedur yang didasarkan pada suatu metode ilmiah. Menurut Sigit (2014), pendekatan scientific merupakan mekanisme untuk memperoleh pengetahuan yang didasarkan pada struktur logis. Pendekatan ini mengaitkan antara matematika dengan ilmu pengetahuan, sehingga siswa akan mempelajari matematika dengan cara yang menarik. Belajar dengan berkegiatan akan berkontribusi terhadap pemahaman matematika siswa. Dengan kata lain, belajar matematika yang baik adalah mengalami atau berkegiatan. Proses pembelajaran scientific merupakan perpaduan antara proses pembelajaran yang semula terfokus pada eksplorasi, elaborasi, dan konfirmasi dilengkapi dengan mengamati, menanya, menalar, mencoba, dan mengomunikasikan (Kemendikbud, 2013).

Proses pembelajaran yang menggunakan pendekatan scientific bertujuan untuk memberikan pemahaman kepada siswa dalam mengenal, memahami berbagai materi menggunakan cara-cara ilmiah. Pendekatan scientific pada kurikulum 2013 yang diterapkan di Indonesia terdiri dari lima langkah yaitu: mengamati, menanya, mengumpulkan informasi, mengasosiasi dan mengomunikasikan (Permendikbud, 2013). Tujuan dari beberapa proses pembelajaran yang harus ada dalam pembelajaran scientific, yaitu menekankan bahwa belajar tidak hanya terjadi di ruang kelas, tetapi juga di lingkungan sekolah dan masyarakat. Selain itu, guru cukup bertindak sebagai fasilitator ketika siswa mengalami kesulitan, serta guru bukan satu-satunya sumber belajar. Sikap tidak hanya diajarkan secara verbal, tetapi melalui contoh dan keteladanan. (Erny, Saleh Haji \&Wahyu Widada, 2017). Dengan demikian, siswa sebenarnya lebih tertantang untuk menemukan sendiri informasi yang diperlukan, mampu mengaitkan pengetahuan yang dimilikinya terhadap pengetahuan baru, mampu menjawab setiap permasalahan dengan baik dan dapat berkomunikasi dengan baik.

Berdasarkan beberapa penelitian yang telah dilakukan, model pembelajaran CORE dapat meningkatkan kemampuan matematis siswa, diantaranya pada penelitian Kumalasari (2011) yang menyatakan bahwa peningkatan kemampuan pemecahan masalah matematis siswa yang belajar dengan model CORE lebih baik daripada siswa yang belajar melalui pembelajaran konvensional. Demikian juga dengan Tamalene (2010) yang menyatakan bahwa kemampuan penalaran matematis siswa yang memperoleh pembelajaran dengan model CORE melalui pendekatan keterampilan kognitif lebih baik daripada siswa yang memperoleh pembelajaran konvensional.

Berdasarkan latar belakang, rumusan masalah dalam penelitian ini adalah Apakah peningkatan kemampuan komunikasi matematis siswa yang memperoleh pembelajaran model CORE dengan pendekatan scientific lebih baik daripada siswa yang memperoleh pembelajaran biasa? Berdasarkan latar belakang dan rumusan masalah yang telah disebutkan, penelitian ini bertujuan untuk menelaah perbedaan peningkatan kemampuan komunikasi matematis antara siswa yang memperoleh pembelajaran model CORE dengan pendekatan scientific dan siswa yang memperoleh pembelajaran biasa.

\section{METODE}

Penelitian ini merupakan penelitian kuasi eksperimen dengan desain NonequivalentControl Group Design. Pada penelitian ini sampel tidak dikelompokkan secara acak murni, tetapi peneliti menerima keadaan sampel sebagaimana adanya untuk tiap kelas yang terpilih. Hal ini didasarkan pertimbangan bahwa kelas telah terbentuk sebelumnya, sehingga tidak dilakukan pengelompokan siswa secara acak. Pengacakan dilakukan untuk memilih dua kelas, masing-masing untuk eksperimen dan kontrol. Kelas yang dipilih terlebih dahulu diuji homogenitasnya. Setelah melibatkan beberapa kelas untuk uji homogenitas, maka dipilihlah dua kelas yang memiliki kesamaan rata-rata secara statistik. 
Penelitian dilakukan pada dua kelompok sampel yaitu kelompok eksperimen dan kelompok kontrol. Kelompok eksperimen adalah kelompok siswa yang memperoleh pembelajaran model CORE dengan pendekatan scientific, sedangkan kelompok kontrol merupakan kelompok siswa yang memperoleh pembelajaran biasa. Populasi dalam penelitian ini adalah seluruh siswa kelas VIII pada semester genap di salah satu SMP Negeri di Priovinsi Jambi tahun ajaran 2014/2015. Alasan pemilihan populasi yaitu karena kemampuan komunikasi matematis siswa SMP tersebut belum pernah diteliti sebelumnya, dan belum mendapat perhatian khusus. Sampel dalam penelitian ini terdiri dari dua kelas, yaitu kelas VIII-D dan kelas VIII-E. Penentuan sampel dilakukan dengan menggunakan teknik "purposive sampling". Tujuannnya agar penelitian dapat dilaksanakan secara efektif dan efisien terutama dalam hal kondisi sampel penelitian, waktu penelitian yang ditetapkan, kondisi tempat penelitian, serta prosedur perijinan.

\section{HASIL DAN PEMBAHASAN}

Hasil penelitian tentang kemampuan komunikasi matematis diperoleh dari hasil pretes yang dilakukan sebelum siswa mendapatkan perlakuan dan hasil postes yang dilakukan setelah siswa mendapatkan perlakuan (pembelajaran). Analisis data pretes dan postes dilakukan untuk melihat perbedaan kemampuan komunikasi matematis siswa antara kelas CORE-scientific dan kelas biasa. Untuk melihat perbedaan peningkatan kemampuan komunikasi matematis digunakan gain ternormalisasi (n-gain). Dari hasil analisis data pretes, postes dan n-gain diperoleh deskripsi kemampuan komunikasi matematis siswa seperti yang terlihat pada Tabel 1.

Tabel 1. Deskripsi Kemampuan Komunikasi Matematis

\begin{tabular}{|c|c|c|c|c|c|c|c|c|c|c|}
\hline \multirow{2}{*}{ Kelas } & $\mathbf{N}$ & $\overline{\boldsymbol{x}}$ & $\boldsymbol{4}$ & $\boldsymbol{s}$ & $\overline{\boldsymbol{x}}$ & $\boldsymbol{4}$ & $\boldsymbol{s}$ & $\overline{\boldsymbol{x}}$ & $\%$ & $\boldsymbol{s}$ \\
\hline $\begin{array}{c}\text { CORE- } \\
\text { Scientific }\end{array}$ & 28 & 2,14 & 13,38 & 1,53 & 10,61 & 66,31 & 1,97 & 0,62 & 62 & 0,11 \\
\hline Biasa & 24 & 1,83 & 11,44 & 1,81 & 6,96 & 43,50 & 2,63 & 0,37 & 37 & 0,14 \\
\hline
\end{tabular}

Skor Ideal Pretes dan Postes $=16$

Tabel 1. menunjukkan bahwa rata-rata hasil pretes dan postes kemampuan komunikasi matematis siswa kelas CORE-scientific dan kelas biasa memiliki perbedaan. Secara grafik perbedaan rata-rata pretes dan postes kemampuan komunikasi matematis disajikan pada Gambar 1. berikut.

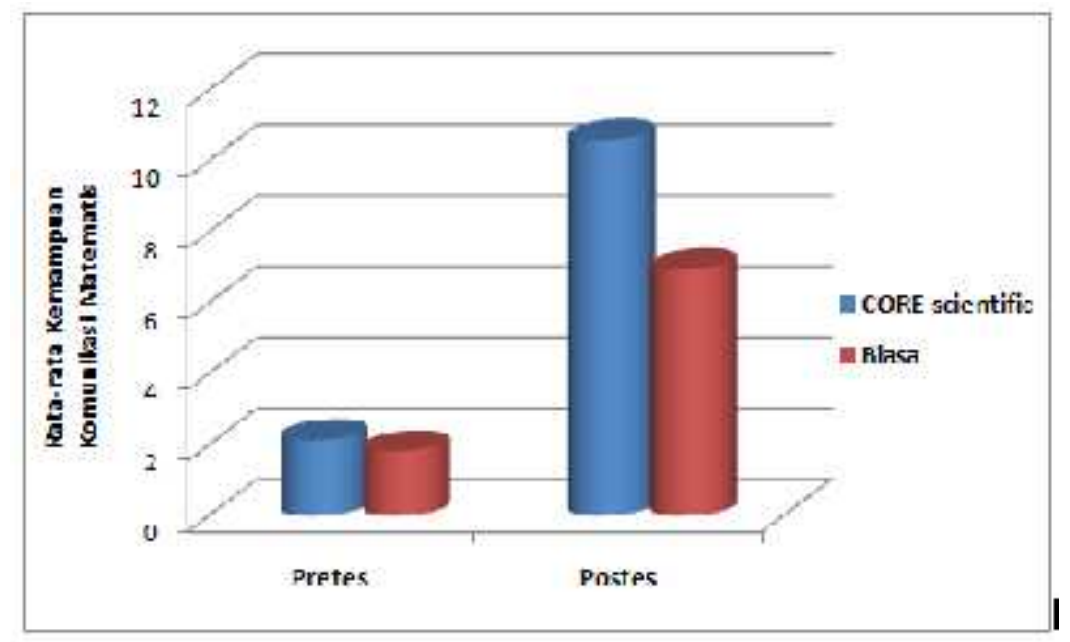

Gambar 1. Rata-rata Hasil Pretes dan Postes Kemampuan Komunikasi Matematis 
Berdasarkan Tabel 1. dan Gambar 1. terlihat bahwa rata-rata hasil pretes kemampuan komunikasi matematis siswa kelas CORE-scientific lebih tinggi daripada kelas biasa. Selisih ratarata hasil pretes pada kelas CORE-scientific dan kelas biasa adalah sebesar 0,31, sehingga dapat dikatakan bahwa kemampuan awal komunikasi matematis siswa pada kelas CORE-scientific dan kelas biasa tidak jauh berbeda. Selain itu, persentase pretes kelas CORE-scientific lebih tinggi daripada kelas biasa dengan selisih sebesar 1,94\%. Hasil dari postes yang terlihat pada Tabel 1. dan Gambar 1. menunjukkan bahwa rata-rata hasil postes kemampuan komunikasi matematis kelas CORE-scientific lebih tinggi daripada kelas biasa. Selisih rata-rata hasil postes kelas COREscientific dan kelas biasa sebesar 3,65, sehingga dapat dikatakan bahwa kemampuan komunikasi matematis siswa pada kelas CORE-scientific dan kelas biasa cukup jauh berbeda. Selain itu, persentase hasil postes kelas CORE-scientific lebih tinggi daripada kelas biasa dengan selisih sebesar $22,81 \%$.

Tabel 1. juga menunjukkan bahwa rata-rata $n$-gain kemampuan komunikasi matematis siswa kelas CORE-scientific dan kelas biasa memiliki perbedaan. Secara grafik perbedaan rata-rata $n$ gain (peningkatan)kemampuan komunikasi matematis disajikan pada Gambar 3.

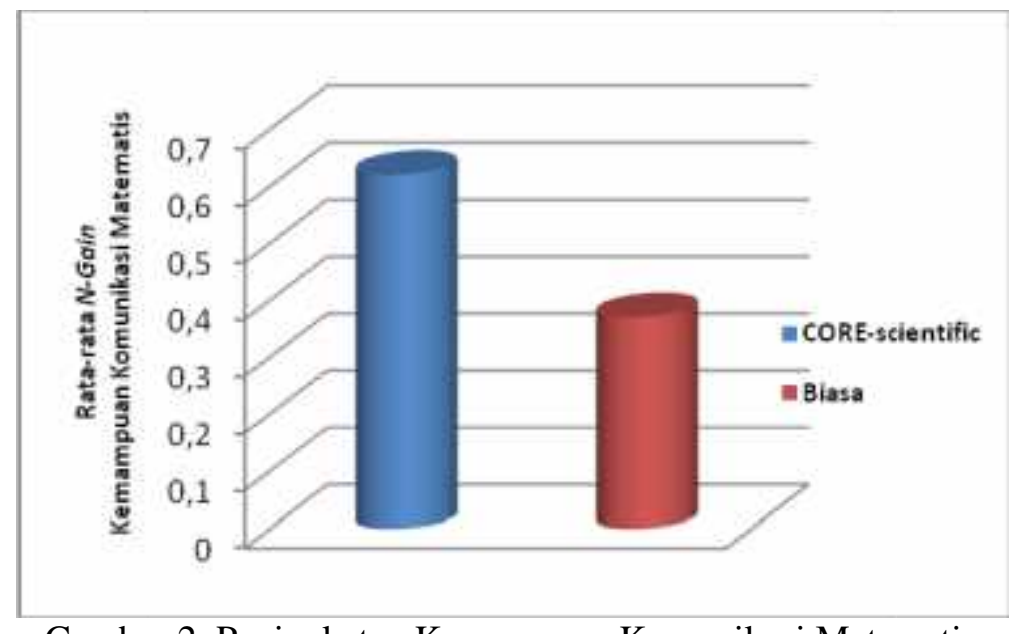

Gambar 2. Peningkatan Kemampuan Komunikasi Matematis

Tabel 1. dan Gambar 2. menunjukkan bahwa rata-rata n-gain kemampuan komunikasi matematis siswa kelas CORE-scientific lebih tinggi daripada kelas biasa. Rata-rata n-gain kelas CORE-scientific adalah 0,62 yang dapat diinterpretasikan dengan peningkatan sedang. Rata-rata $n$ gain pada kelas biasa adalah 0,37 yang dapat diinterpretasikan dengan peningkatan sedang. Selisih rata-rata $n$-gain kelas CORE-scientific dan kelas biasa sebesar 0,25 , sehingga dapat dikatakan bahwa peningkatan kemampuan komunikasi matematis siswa pada kelas CORE-scientific dan kelas biasa cukup jauh berbeda. Selain itu, persentase $n$-gain kelas CORE-scientific lebih tinggi daripada kelas biasa dengan selisih sebesar 25\%. Perbedaan peningkatan kemampuan komunikasi matematis siswa kelas CORE-scientific pada setiap indikator disajikan pada Gambar 4. 


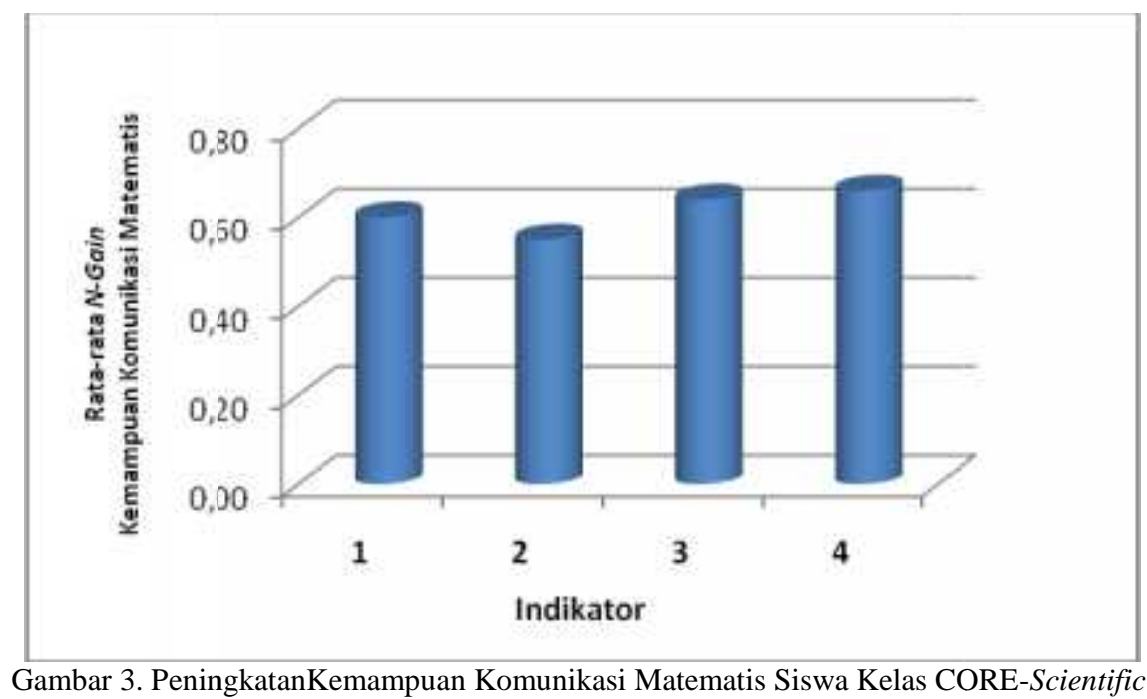

Berdasarkan Gambar 3. terlihat peningkatan kemampuan komunikasi matematis pada kelas CORE-scientific pada indikator 1 yaitu menghubungkan benda nyata, gambar, atau diagram ke dalam ide matematis sebesar 0,60 yang dapat diinterpretasikan dengan peningkatan sedang. Pada indikator 2 yaitu menyatakan suatu situasi atau masalah ke dalam bentuk gambar, diagram, grafik, atau ekspresi matematis tejadi peningkatan sebesar 0,55 yang dapat diinterpretasikan dengan peningkatan sedang. Pada indikator 3 yaitu menyatakan peristiwa sehari-hari dalam bahasa atau simbol matematis tejadi peningkatan sebesar 0,64 yang dapat diinterpretasikan dengan peningkatan sedang. Peningkatan paling tinggi terdapat pada indikator 4 yaitu membuat konjektur dan menyusun argumen, dengan peningkatan sebesar 0,66 yang dapat diinterpretasikan dengan peningkatan sedang.

Secara umum, dapat dikatakan bahwa terdapat perbedaan rata-rata hasil pretes, postes dan $n$ gain kemampuan komunikasi matematis pada kelas CORE-scientific dan kelas biasa. Namun, perlu dilakukan uji perbedaan rata-rata untuk menunjukkan bahwa rata-rata hasil pretes, postes dan $n$ gain kemampuan komunikasi matematis antara kelas CORE-scientific dan kelas biasa berbeda atau tidak secara signifikan. Dengan demikian, dapat diketahui bahwa kemampuan awal, kemampuan akhir dan peningkatan kemampuan komunikasi matematis siswa kelas CORE-scientific lebih baik atau tidak secara signifikan daripada kelas biasa.

Untuk mengetahui signifikansi perbedaan rata-rata peningkatan kemampuan komunikasi matematis siswa kelas CORE-scientific dan kelas biasa digunakan uji statistik Independent ttest.Rangkuman hasil perhitungannya disajikan pada Tabel 2.

Tabel 2. Hasil Uji Perbedaan Rata-rata N-gain Kemampuan Komunikasi Matematis Siswa Kelas CORE-Scientific dan Kelas Biasa

\begin{tabular}{cccc}
\hline T & df & Sig. & Kesimpulan \\
\hline 7,220 & 50 & 0,000 & $\mathrm{H}_{0}$ ditolak \\
\hline
\end{tabular}

Berdasarkan Tabel 2. diketahui nilai signifikansi (sig.) uji perbedaan rata-rata $n$-gain lebih kecil dari $\alpha=0,05$, sehingga $\mathrm{H}_{0}$ ditolak. Artinya rata-rata n-gain kemampuan komunikasi matematis siswa kelas CORE-scientific lebih baik secara signifikan daripada rata-rata $n$-gain kemampuan komunikasi matematis siswa kelas biasa. Jadi, dapat disimpulkan bahwa peningkatan kemampuan komunikasi matematis siswa yang memperoleh pembelajaran model CORE dengan pendekatan scientific lebih baik secara signifikan daripada siswa yang memperoleh pembelajaran biasa.

Perbedaan kemampuan komunikasi matematis siswa kelas CORE-scientific dan kelas biasa terlihat pada jawaban siswa dari soal tes kemampuan komunikasi matematis. Berikut soal dan perbedaan jawaban siswa kelas CORE-scientific dan kelas biasa. 
"Wira akan membuat sebuah meja yang permukaannya berbentuk lingkaran dengan diameter $x \mathrm{~cm}$. Biaya untuk membuat meja Rp 80.000,00/ $\mathrm{m}^{2}$. Buatlah model matematika untuk menentukan biaya yang diperlukan Windra dalam membuat meja tersebut!"

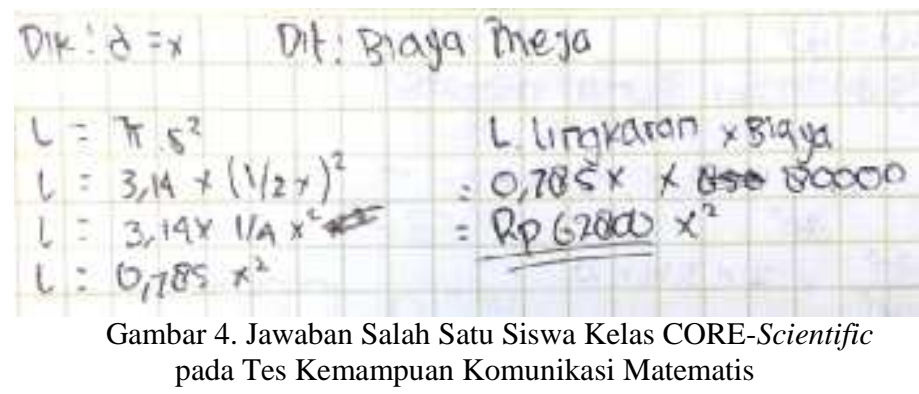

Gambar 4. merupakan salah satu jawaban siswa kelas CORE-scientific pada indikator menyatakan peristiwa sehari-hari dalam bahasa atau simbol matematis. Siswa kelas COREscientific mampu membuat model matematis berdasarkan permasalahan yang diberikan. Siswa terlebih dahulu menentukan luas meja berdasarkan yang diketahui. Siswa juga sudah mampu memahami bahwa jika diameternya adalah $x$, maka jari-jarinya $1 / 2 x$. Meskipun siswa tidak menuliskan di lembar jawaban, namun berdasarkan jawabannya saat menentukan luas meja, terlihat ia memahami bahwa jari-jarinya $1 / 2 x$. Setelah menentukan luas meja, siswa mengalikan luas meja dengan biaya untuk membuat meja per $\mathrm{m}^{2}$. Dengan demikian, ditemukan model matematis untuk menentukan biaya yang diperlukan Wira dalam membuat meja. Dari Gambar 4 juga terlihat bahwa siswa memahami maksud variabel $x$ pada soal, sehingga siswa mampu menemukan model matematis yang masih memuat variabel $x$ sesuai dengan apa yang tanyakan pada soal. Adapun jawaban siswa kelas biasa ditunjukkan pada Gambar 5. berikut.

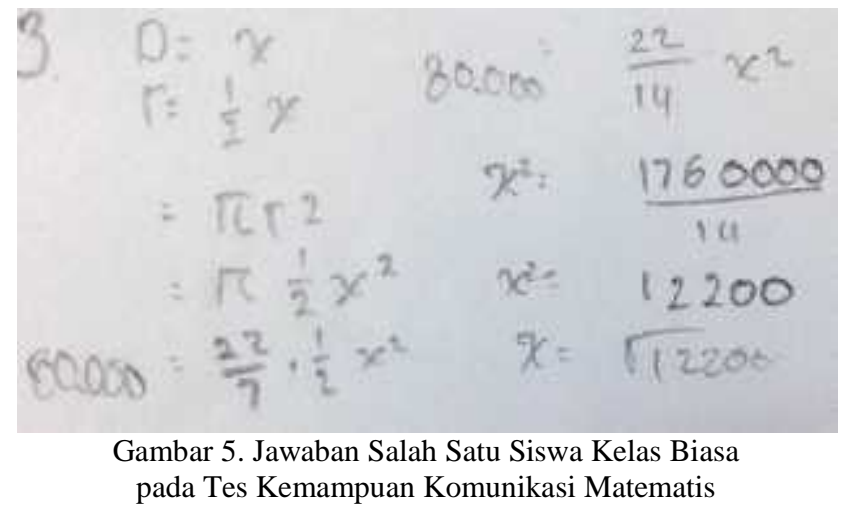

Berdasarkan Gambar 5. terlihat bahwa siswa kelas biasa belum mampu membuat model matematis berdasarkan permasalahan yang diberikan. Siswa sudah mengetahui bahwa diameternya $x$ dan jari-jarinya $1 / 2 x$. Siswa menentukan luas meja terlebih dahulu, namun siswa keliru dalam mengkuadratkan jari-jari. Siswa juga kesulitan menemukan model matematis karena terdapat variablex. Siswa berusaha menemukan nilai $x$ tersebut. Dari jawaban siswa pada Gambar 5. terlihat bahwa siswa belum sepenuhnya memahami maksud dari pertanyaan pada soal dan siswa belum mampu membuat model matematis dari permasalahan pada soal.

Berdasarkan jawaban siswa pada Gambar 4. dan Gambar 5. terlihat bahwa jawaban siswa kelas CORE-scientific lebih baik daripada kelas biasa. Dari hasil analisis $n$-gain juga menunjukkan bahwa peningkatan kemampuan komunikasi matematis siswa yang memperoleh pembelajaran model CORE dengan pendekatan scientific lebih baik daripada siswa yang memperoleh pembelajaran biasa. Peningkatan yang paling tinggi terdapat pada indikator membuat konjektur dan menyusun argumen sebesar 0,66 yang dapat dikategorikan sedang. 
Terjadinya peningkatan kemampuan komunikasi matematis pada indikator "membuat konjektur dan menyusun argumen" dikarenakan pada tahap reflecting siswa terbiasa menyelesaikan permasalahan yang terdapat pada LKS. Pada tahap ini, siswa dituntut untuk menganalisis dan menyusun argumen terhadap solusi yang diperoleh dari permasalahan yang diberikan. Selain itu, pada tahap extending, siswa menjelaskan ide-ide mereka di depan kelas. Hal ini menuntut siswa untuk menyusun argumen terhadap solusi dari permasalahan yang diberikan. Seperti yang dikatakan Yackel, et al (dalam Cotton, 2008) bahwa dalam diskusi kelompok kecil, ketika siswa menemukan perbedaan solusi dengan teman-temannya, siswa harus mencoba memahami interperetasi teman-temannya dan kemudian merumuskan argumen berdasarkan solusi yang diperoleh. Selain menjelaskan ide-ide mereka, pada tahap ini siswa dituntut untuk mengajukan pertanyaan atau memberikan tanggapan terhadap hasil diskusi yang dilakukan kelompok lain. Akibatnya, siswa akan terbiasa menyusun dan memberikan argumen seperti yang dijelaskan Hosnan (2014, hlm. 103) bahwa dengan bertanya, akan mendorong partisipasi siswa dalam berdiskusi, berargumen, mengembangkan kemampuan berpikir, dan menarik kesimpulan.

Secara umum, hal-hal yang mendukung peningkatan kemampuan komunikasi matematis siswa yang memperoleh pembelajaran model CORE dengan pendekatan scientific lebih baik daripada siswa yang memperoleh pembelajaran biasa, diantaranya karena siswa pada kelas COREscientific terbiasa menyelesaikan suatu permasalahan yang diberikan pada LKS seperti mengamati suatu objek/benda kemudian menyatakan dalam ide matematis. Siswa terbiasa membuat model matematis sebagai solusi dari permasalahan yang diberikan pada LKS. Selain itu, pada tahap organizing, siswa terbiasa mengorganisasikan pengetahuannya untuk menyelesaikan masalah yang diberikan. Hal ini merupakan langkah penting dalam mengomunikasikan ide matematis, seperti yang dijelaskan NCTM (2000, hlm. 129) bahwa sebuah langkah penting dalam mengomunikasikan pemikiran matematis kepada orang lain adalah mengorganisasikan (organizing) dan mengklarifikasi ide-ide seseorang.

Pada tahap reflecting, siswa memikirkan secara mendalam terhadap konsep yang dipelajarinya yaitu dengan memikirkan kembali, mendalami, dan menggali informasi yang sudah didapat, mengolah informasi yang sudah dikumpulkan kemudian dianalisis dan menyimpulkan dari hasil analisis. Hal ini juga mendukung meningkatnya kemampuan komunikasi matematis siswa seperti yang dijelaskan NCTM (2000, hlm. 61) bahwa refleksi dan komunikasi merupakan proses yang saling berkaitan dalam pembelajaran matematika. Ketika siswa mampu merefleksikan idenya seperi menganalisis dan menyimpulkan, maka hal tersebut akan membantu siswa mengomunikasikan ide mereka. Selanjutnya, pada tahap extending yaitu tahap siswa memperluas pengetahuan yang mereka peroleh selama proses belajar mengajar berlangsung dengan cara mengomunikasikan gagasannya dan mendengarkan pendapat dari yang lain baik dalam diskusi maupun peresentasi yang dilakukan di setiap pembelajaran. Pada pendekatan scientific siswa juga dilatih untuk mengomunikasikan idenya. Dengan proses ini maka siswa terbiasa menyatakan dan mengungkapkan ide-ide mereka, baik dalam bertanya ataupun menanggapi pertanyaan.

Hal-hal yang telah diuraikan di atas merupakan beberapa faktor yang menyebabkan meningkatnya kemampuan komunikasi matematis siswa pada kelas CORE-scientific atau siswa yang memperoleh pembelajaran model CORE dengan pendekatan scientific. Dengan demikian, dapat disimpulkan bahwa pembelajaran model CORE dengan pendekatan scientific dapat membantu siswa dalam meningkatkan kemampuan komunikasi matematis (Hariyanto, 2016; Humaira, et.al, 2014) .

\section{KESIMPULAN}

Peningkatan kemampuan komunikasi matematis siswa yang memperoleh pembelajaran model CORE dengan pendekatan scientific lebih baik daripada siswa yang memperoleh pembelajaran biasa. Peningkatan kemampuan komunikasi matematis siswa yang memperoleh pembelajaran model CORE dengan pendekatan scientific berada pada klasifikasi sedang. 


\section{DAFTAR RUJUKAN}

Baroody, A. (1998). Fostering Children's Mathematical Power. New Jersey: Lawrence Erlbaum.

Calfee, dkk. (2004). Making Thinking Visible.Riverside: University of California.

Cotton, K.H. (2008). Mathematical Communication, Conceptual Understanding, and Students' Attitudes toward Mathematics. Nebraska: University of Nebraska-Lincoln.

Erny, Saleh Haji, Wahyu Widada (2017). Pengaruh Pendekatan Saintifik pada Pembelajaran Matematika Terhadap Kemampuan Pemecahan Masalah dan Kemampuan Berpikir Tingkat Tinggi Siswa Kelas X IPA SMA Negeri 1 Kepahiang. Jurnal Pendidikan Matematika Raflesia, 2(1)

Fadhilah Al Humaira, Suherman, Jazwinarti. (2014) Penerapan Model Pembelajaran CORE pada Pembelajaran Matematika Siswa Kelas X SMAN 9 Padang, Jurnal Pendidikan Matematika, 3 (1), 31-37

Hariyanto (2016) Penerapan Model CORE dalam Pembelajaran Matematika untuk Meningkatkan Kemampuan Komunikasi Matematik Siswa, Jurnal Gammath, 1(2), 33-40

Hosnan. (2014). Pendekatan Saintifik dan Kontekstual dalam Pembelajaran Abad 21. Jakarta: Ghalia Indonesia.

Kementerian Pendidikan dan Kebudayaan. (2013). Pengembangan Kurikulum 2013. Paparan Mendikbud dalam Sosialisasi Kurikulum 2013. Jakarta: KemdikbudNational Council of Teachers of Mathematics. (2000). Principles and Standards for School Mathematics. Reston, Virginia: NCTM.

Kumalasari, E. (2011). Peningkatan Kemmapuan Berpikir Kritis dan Pemecahan Masalah Matematis Siswa SMP Melalui Pembelajaran dengan Model CORE. (Tesis). SPs UPI, Bandung.

Peraturan Menteri Pendidikan dan Kebudayaan Republik Indonesia Nomor 64 Tahun 2013 tentang Standar Isi Pendidikan Dasar dan Menengah.

Sigit. (2014). Pendekatan Saintifik dalam Matematika. Lokakarya School Community P4TK.

Sumarmo, U. (2010). Berfikir dan Disposisi Matematik: Apa, Mengapa, dan Bagaimana dikembangkan Pada Peserta Didik: Bandung: FPMIPA UPI.

Sumarmo, U. (2014). Pengembangan Hard Skill dan Soft Skill Matematik Bagi Guru dan Siswa Untuk Mendukung Implementasi Kurikulum 2013. Jurnal Pendidikan Matematika STKIP Siliwangi. 1, ISSN 2355-0473.

Tamalene, H. (2010). Pembelajaran Matematika dengan Menggunakan Model CORE Melalui Pendekatan Keterampilan Metakognitif untuk Meningkatkan Kemampuan Penalaran Matematis Siswa Sekolah Menengah Pertama. (Tesis). SPs UPI, Bandung.

Wijayanti, A. (2012). Penerapan Model Connecting, Organizing, Reflecting, Extending (CORE) untuk Meningkatkan Kemampuan Pemecahan Masalah Matematis siswa SMP. [Online]. Diakses dari http://www.repository.upi.edu/operator/skripsiview.

Zulkarnain, I. (2013). Kemampuan Pemahaman dan Komunikasi Matematis Siswa dalam Pembelajaran Kooperatif Berbasis Konflik Kognitif. (Disertasi). SPs UPI, Bandung. 